\title{
Quality of life in monogenic diabetes (a case report)
}

\author{
Nur Rochmah*, Muhammad Faizi, Ahmad Yuniari, EP Netty \\ From 7th APPES Biennial Scientific Meeting \\ Nusa Dua, Bali. 14-17 November 2012
}

Monogenic diabetes in children mostly results from mutations in genes that regulate beta-cell function. It may be dominantly or recessively inherited or may be a de novo mutation and hence a spontaneous case. Quality of life is important in management of patient with monogenic diabetes. Objective is to analyze quality of life in a patient with monogenic diabetes.

A-19year old, girl, $29.5 \mathrm{~kg}$, sufferred from polyuria, polydipsia, and polyphagia. Family history of diabetes was positive. Physical examination revealed non obese, with colateral vein, and hepatosplenomegaly. Laboratory examination revealed fasting blood glucose $275 \mathrm{mg} / \mathrm{dL}$, hemoglobin $\mathrm{A}_{1 \mathrm{C}} / \mathrm{A} 1 \mathrm{C} 10.3 \%$, C-peptide $4.2 \mathrm{ng} / \mathrm{mL}$ (normal:0.9-7.1ng/mL), ALT:110 U/L, AST:115 U/L; HDL:70 $\mu \mathrm{g} / \mathrm{dL}$, LDL: $57 \mathrm{mg} / \mathrm{dL}$, total cholesterol:319mg/dL, and triglyceride: $2030 \mathrm{mg} / \mathrm{dL}$. Liver biopsy revealed hepatosteatosis. She was diagnosed with monogenic diabetes and Nonalcoholic Steatohepatitis (NASH). Patient was given glibenclamide $5 \mathrm{mg}$ twice daily; insulin detemir $14 \mathrm{IU}$; metformin $500 \mathrm{mg}$ twice daily, with uncooked corn starch. After three months of treatment random blood glucose became $132 \mathrm{mg} / \mathrm{dL}$ and A1C became 7.7\%; insulin was stopped. Seven months later random blood glucose increased to $287.5 \mathrm{mg} / \mathrm{dL}$, ALT: $204 \mathrm{U} / \mathrm{L}$, and AST: $257 \mathrm{U} / \mathrm{L}$. Insulin was readminestered and glibenclamide were increased to three times daily. A1C evaluation revealed 5.7\%. Diabetic nephropathy (DN) occurred, but after a month of captopril, proteinuria was improved from $2.8 \mathrm{~g} / 24 \mathrm{hrs}$ to $1.5 \mathrm{~g} / 24 \mathrm{hrs}$. Diet for DN was put to therapy. No retinopathy was found. Measurement of quality of life using Diabetes Quality of life (DQOL) revealed satisfaction with life $65.8 \%$, impact of diabetes $55 \%$, worries about diabetes $50.9 \%$, and overall her health was poor. Conclusion is hyperglycemia, nonalcoholic steatohepatitis, hypertriglycemia, and diabetic nephropathy

Department of Child Health, School of Medicine, Airlangga University-Dr Soetomo Hospital, Surabaya, Indonesia reported as clinical course of monogenic diabetes. The quality of life revealed satisfaction.

Published: 3 October 2013

doi:10.1186/1687-9856-2013-S1-P25

Cite this article as: Rochmah et al:: Quality of life in monogenic 2013 2013(Suppl 1):P25.

Submit your next manuscript to BioMed Central and take full advantage of:

- Convenient online submission

- Thorough peer review

- No space constraints or color figure charges

- Immediate publication on acceptance

- Inclusion in PubMed, CAS, Scopus and Google Scholar

- Research which is freely available for redistribution 